\title{
Editorial
}

\section{Faster, Higher, Stronger}

During her confirmation hearing at the European Parliament, Commissioner-designate for Competition Margrethe Vestager was remarkably candid in recognizing that antitrust enforcement moves far too slow to keep pace with fast-moving markets. Digital markets with winner-takes-most dynamics pose particular challenges. Once a market has tipped and network externalities are strong, 'fines do not do the trick', Vestager conceded, and merely putting a stop to unlawful conduct is insufficient to restore effective competition.

The three Google cases exemplify that lengthy antitrust proceedings often do too little, too late. The investigations lasted on average 7.5 years. And the prohibition decisions arrived long after competition for the market for general Internet search (and several adjacent markets) was won by Google. Two years after Google introduced its auction-based remedy, traffic from Google's general search results pages to competing shopping comparison services has not meaningfully increased. ${ }^{1}$ In relation to the Google AdSense case, where Google ceased the contested practices after the European Commission issued a Statement of Objections in 2016, Vestager similarly noted that the 'market hasn't picked up'. ${ }^{2}$

When asked how the Commission could speed up antitrust enforcement and make it more effective, Vestager pointed towards the potential use of interim measures. The Commission recently imposed, for the first time in nearly two decades, such measures on Broadcom, ordering the semiconductor manufacturer to stop applying allegedly anti-competitive exclusivity clauses in selected customer agreements.

Interim measures are indeed an effective tool to avoid that harm to competition can no longer be reversed upon conclusion of the investigation on the merits. Yet the procedural requirements are considerable. And it is challenging to satisfy the strict substantive requirements other than in clear-cut cases (and perhaps for good reasons as the welfare costs of mistaken intervention can be significant). Hence, in complex and dynamic markets the use of interim measures may often not be possible and/or appropriate.

So, should we then consider new tools for expedited enforcement action?

At her confirmation hearing, Vestager said that she is keen to explore the ex ante instrument put forward by the Dutch government and recently endorsed by the Belgian,

1 Foo Yun Chee and Victoria Waldersee, 'EU's Vestager says Google's antitrust proposal not helping shopping rivals' Reuters (7 November 2019) <https://www.reuters.com/article/us-eu-alphabet-antitrust/eus-vestager-says-googles-antitrust-proposal-not-helping-shopping -rivals-idUSKBN1XH2l8> accessed 11 November 2019

2 European Parliament, 'Verbatim report of hearing of Margrethe Vestager' (8 October 2019) <https://www.europarl.europa.eu/resources/library/ media/20191009RES63801/20191009RES63801.pdf> accessed 11 November 2019 
Dutch, and Luxembourg competition authorities. The proposed tool would extend the enforcement toolkit of Regulation 1/2003. It would entitle the European Commission and the national competition authorities (NCAs) to impose behavioral remedies (such as platform access, data portability, data-sharing, and non-discriminatory ranking) on dominant undertakings in order to prevent them from abusing that position. As opposed to interim measures or commitment decisions, the use of this tool would not require a (prima facie) finding of an infringement. Its non-punitive nature would facilitate a constructive dialogue with the dominant undertaking as it is not accused of any wrongdoing and faces no (potential subsequent) sanctions if it accepts the findings of the competition authorities' assessment. $^{3}$

The conceptual design of the proposed ex ante enforcement tool, which is loosely inspired by the UK market investigation regime and the EU telecoms regulatory framework, is clearly far from complete. The scope of the application of the instrument remains unclear. The suggested focus on undertakings that have a 'dominant position' in the meaning of Article 102 TFEU is arguably too broad (in which markets?) and too narrow at the same time (considering in particular that a prospective analysis may well lead to different outcomes regarding market definition and complicate the finding of dominance). And perhaps most critically, the Benelux competition authorities are silent as to the legal threshold for remedial action. The choice of this threshold (effects-based or not) would greatly influence the added value of the tool.

That said, the outlook of the proposal - a participative, hybridised form of ex ante and ex post intervention - is worth exploring. In situations where 'dominant' platforms de facto regulate and govern other parties' access to one or more digital markets, it is a sensible idea to promote and co-design preventive 'compliance' measures that safeguard opportunities for competition. A similar suggestion has been made in the Furman 'Unlocking digital competition' report. The ex ante tool proposed by the Benelux competition authorities, however, would provide for tailor-made measures (rather than a code of conduct that would apply to a wide variety of platforms) and could be closely aligned with competition law concepts and methodologies (and by extension ex post antitrust enforcement). At the very least, it would allow behavioural remedies to be tested and fine-tuned with a view to potential commitments or final remedies - if it comes to that - that might prove more effective in inducing entry and restoring competition. And at best, it would preempt slow-paced ex post antitrust enforcement altogether.

This last issue of 2019 features a number of articles exploring key elements of the procedural and evidential framework of EU competition law. In Revaluing the role of intent evidence in EU antitrust law, Jan Blockx scrutinises the arguments against the use of evidence of intentions in antitrust cases and develops the argument that such evi-

3 Joint Memorandum of the Belgian, Dutch and Luxembourg competition authorities on challenges faced by competition authorities in a digital world (2 October 2019) <https://www.belgiancompetition.be/en/about-us/publications/joint-memorandum-belgian-dutch-and -luxembourg-competition-authorities> accessed 11 November 2019. 
dence has a valuable role to play when determining whether an infringement took place and when imposing sanctions on it. In Balance between effectiveness and fundamental rights in Article 101 TFEU, Baskaran Balasingham analyses how the EU Courts have ensured that there is an adequate balance between the need for effective cartel enforcement and the protection of fundamental rights. In Competition authorities' decisions and antitrust damages actions, Ignacio García-Perrote Martínez examines the role of decisions adopted by the Commission and NCAs in easing the claimants' burden of proof in the context of follow-on antitrust damages actions. And in Public Interest in Merger Control Systems in the EU and US, Giancarlo Piscitelli comparatively explores the treatment of public interest considerations in EU and US merger control.

The Reports section of this issue offers an insightful overview of important competition law and regulatory law developments in Austria, Italy, Luxembourg, Poland, and Slovenia. We also have two case notes, commenting on the General Court's Slovak Telekom judgment and the European Commission's decision fining Asus, Denon \& Marantz, Philips, and Pioneer for resale price maintenance on the online retail market of consumer electronics. Finally, this issue includes book reviews of Paul Nihoul and Pieter Van Cleynenbreugel's The Roles of Innovation in Competition Law Analysis and Florence Thépot's The Interaction between Competition Law and Corporate Governance: Opening the Black Box. 